\title{
Effects of organic acid and probiotic on performance and gut morphology in broiler chickens
}

\author{
A.F. Agboola, B.R.O. Omidiwura, O. Odu, I.O. Popoola \& E.A. Iyayi" \\ Department of Animal Science, University of Ibadan, Ibadan, Nigeria
}

(Received 21 February 2015; Accepted 18 June 2015; First published online 2 December 2015)

\begin{abstract}
Copyright resides with the authors in terms of the Creative Commons Attribution 2.5 South African Licence.
See: http://creativecommons.org/licenses/by/2.5/za

Condition of use: The user may copy, distribute, transmit and adapt the work, but must recognise the authors and the South African Journal of Animal Science.
\end{abstract}

\begin{abstract}
The effects of organic acid, probiotic and a combination of the two on performance and gut morphology in broiler chickens were investigated. Two hundred and forty one-day-old Arbor Acre broiler chicks were randomly assigned to five dietary treatments with six replicates, each with eight birds. The treatments were basal diet (negative control, NC), basal diet + antibiotic (positive control (PC)), NC $+0.4 \%$ organic acid (OA), NC $+0.3 \%$ probiotic $(\mathrm{PB})$ and $\mathrm{NC}+0.4 \% \mathrm{OA}$ and $0.3 \% \mathrm{~PB}$. Reduced body weight gain (BWG) was recorded for birds on the NC diet at the starter phase and over the total period. The addition of OA significantly increased BWG compared to values obtained in birds on the NC and other diets. Diet had no effect on BWG at the grower phase or on feed intake, dry matter intake and feed conversion ratio in any growth phase. Gain : feed ratio was lowered in the NC diet, but improved significantly by OA and PB in the starter phase. Organic acid supplementation reduced the weight of the bursa of Fabricius. The weight of pancreas, height of villi and crypt depth were reduced in birds on the NC diet compared with those on OA, PB and a combination of these. Diet had no effects on the weights of the lungs, heart, spleen, kidneys, liver, villus width, villus height : crypt depth ratio, lactic acid bacteria, coliform bacteria and total bacterial count in any gut section. In conclusion, supplementation of broiler diets with OA and PB could improve their growth and gut morphology better than antibiotics would, with a greater positive effect in the starter phase.
\end{abstract}

Keywords: Broiler chickens, gut health, organic acids, performance, probiotics

\# Corresponding author: eaiyayi@yahoo.com

\section{Introduction}

Vulnerability of poultry to potentially pathogenic microorganisms such as Escherichia coli, Salmonella spp. and Clostridium perfringens has been reported, with pathogenic microflora being established in the small intestine, thereby competing with the host for nutrients and reducing the digestion of fat and fat-soluble vitamins owing to the deconjugating effects of bile acids (Engberg et al., 2000). This depresses growth performance and increases the incidence of disease. Antibiotics have been used for several decades to combat certain pathogenic diseases in farm animals and improve their growth. The inherent dangers in this include increased resistance by pathogens to antibiotics, and residual amounts of antibiotics in animal products, which have been reported by several authors (Truscott \& Al-Sheikhly, 1977; Miles et al., 1984; Waldroup et al., 1985; Hernandez et al., 2006; Pirgozliev et al., 2008). Although the inclusion of antibiotics in feed has been banned in the EU countries, such legislation has yet to take place in many other countries, including Nigeria, where antibiotics are still used in animal feeding. However, viable alternatives must be sought that would enhance the natural defence mechanisms of animals and reduce the massive use of antibiotics because of their potential hazards. Organic acids, probiotics and prebiotics have been shown to reduce serum cholesterol and the abdominal fat of broiler chickens (Yusrizal \& Chen, 2003; Gaggia et al., 2010), increase performance, improve resistance to pathogenic bacteria colonization and enhance host mucosa immunity, resulting in reduced pathogen load and improved health status of the animal (Yalcinkaya et al., 2008). Angel et al. (2005), Yang et al. (2008) and Pirgozliev et al. (2008) reported beneficial effects of dietary additives such as organic acids and probiotics on energy and protein utilization in poultry. Some studies have been conducted to determine the effects of these feed additives on growth indices, serum biochemical parameters and carcass characteristics of broiler chickens (Ashayerizadeh et al., 2011). However, there is a paucity of information on the efficiency of a combination of probiotic and organic acid supplementation in broiler chickens. It was the aim of this study to investigate the effects of organic acid, 
probiotics and their combination on the performance, organ weight, gut morphology and microflora in broilers.

Table 1 Gross composition of experimental diets fed at starter and grower phases

\begin{tabular}{|c|c|c|}
\hline \multirow{2}{*}{ Ingredients, g/kg } & \multicolumn{2}{|c|}{ Basal diet } \\
\hline & Starter phase & Grower phase \\
\hline Maize & 560 & 640 \\
\hline Soybean meal & 300 & 235 \\
\hline Fish meal & 75.0 & 80.0 \\
\hline Soybean oil ${ }^{1}$ & 35.7 & 15.7 \\
\hline Dicalcium phosphate & 19.2 & 19.5 \\
\hline Min.-vit. premix ${ }^{2}$ & 1.60 & 1.60 \\
\hline Limestone $^{3}$ & 4.00 & 4.00 \\
\hline Methionine & 1.00 & 1.00 \\
\hline Lysine & 1.00 & 1.00 \\
\hline Salt & 2.50 & 2.50 \\
\hline Antibiotics & 0 & 0 \\
\hline Acidifier & 0 & 0 \\
\hline Probiotic & 0 & 0 \\
\hline Total & 1000 & 1000 \\
\hline \multicolumn{3}{|l|}{ Calculated analysis } \\
\hline Crude protein $\mathrm{g} / \mathrm{kg}$ & 225 & 206 \\
\hline Metabolisable energy $\mathrm{MJ} / \mathrm{kg}$ & 13.0 & 12.7 \\
\hline Calcium g/kg & 10.5 & 10.7 \\
\hline Total phosphorus $\mathrm{g} / \mathrm{kg}$ & 8.91 & 8.88 \\
\hline Non-phytate $P, g / k g$ & 4.49 & 4.40 \\
\hline $\mathrm{Ca}:$ Total P & 1.18 & 1.20 \\
\hline $\mathrm{Ca}$ : non-phytate $\mathrm{P}$ & 2.34 & 2.42 \\
\hline \multicolumn{3}{|l|}{ Amino acid, $\mathrm{g} / \mathrm{kg}$} \\
\hline Lysine & 13.9 & 12.6 \\
\hline Methionine & 5.09 & 4.91 \\
\hline Cystine & 3.42 & 3.16 \\
\hline Threonine & 18.0 & 19.0 \\
\hline Tryptophan & 2.92 & 2.51 \\
\hline Valine & 10.5 & 9.64 \\
\hline
\end{tabular}

\footnotetext{
${ }^{1}$ The amount of sunflower oil was reduced to accommodate the inclusion levels of antibiotic $(1 \mathrm{~g} / \mathrm{kg})$, acidifier $(4 \mathrm{~g} / \mathrm{kg})$ and probiotic $(3 \mathrm{~g} / \mathrm{kg})$ in the positive control $(\mathrm{PC})$, organic acid $(\mathrm{OA})$, probiotic $(\mathrm{P})$ and $\mathrm{OA}+\mathrm{P}$ diets. The amounts of ingredients across diets were the same in the starter and grower phases.

${ }^{2}$ Supplied per kg diet: 5484 IU vitamin A; 2643 ICU vitamin $D_{3} ; 11$ IU vitamin E; 4.38 mg menadione sodium bisulphite; $5.49 \mathrm{mg}$ riboflavin; $11 \mathrm{mg}$ d-pantothenic acid; $44.1 \mathrm{mg}$ niacin; $771 \mathrm{mg}$ choline chloride; $13.2 \mu \mathrm{g}$ vitamin $\mathrm{B}_{12}$;

$55.2 \mu \mathrm{g}$ biotin; $2.2 \mathrm{mg}$ thiamine mononitrate; $990 \mu \mathrm{g}$ folic acid; $3.3 \mathrm{mg}$ pyridoxine hydrochloride; $1.11 \mathrm{mg} \mathrm{l;} 66.06 \mathrm{mg} \mathrm{Mn}$; $4.44 \mathrm{mg} \mathrm{Cu} ; 44.1 \mathrm{mg} \mathrm{Fe} ; 44.1 \mathrm{mg} \mathrm{Zn} ; 300 \mu \mathrm{g} \mathrm{Se}$.

${ }^{3} 37 \% \mathrm{Ca}$.
}

\section{Materials and Methods}

Two hundred and forty one-day-old Arbor Acre broiler chicks, with an average initial bodyweight of $43 \mathrm{~g}$, were obtained from a local commercial poultry farm ( $\mathrm{CHI}$ Ajanla Farms, Ibadan). The birds were 
weighed and allocated to 30 pens, each with eight birds. Six replicate pens were then randomly allotted to each of the five dietary treatments, and reared in two phases (starter phase, d 0 - 21 and grower phase, $d 22$ - 35). Diet 1 (negative control (NC)) was a basal diet with no antibiotics, organic acid (OA) or probiotics (PB). Diet 2 (positive control (PC)) was the basal diet + oxytetracycline, added at the rate of $0.105 \mathrm{~g} / \mathrm{kg}$. Diet 3 comprised NC $+4 \mathrm{~g} / \mathrm{kg}$ OA (Acidomix AFG, consisting of $207000 \mathrm{mg}$ formic acid $/ \mathrm{kg}, 175000 \mathrm{mg}$ ammonium formate $/ \mathrm{kg}$ ), $128000 \mathrm{mg}$ propionic acid $/ \mathrm{kg}$ and $42000 \mathrm{mg}$ ammonium propionate $/ \mathrm{kg}$ ). Diet 4 consisted of NC $+0.3 \%$ PB (Lactobacillus sporogenes, 50 million CFU, and Saccharomyces cerevisiae, $1.5 \times 10^{8} \mathrm{CFU}$ ). Diet 5 consisted of NC + OA and PB. The birds were fed in groups of eight, and records of feed intake and body weight gain were used to compute feed conversion ratio per bird. Feed and water were given ad libitum.

The feed for both starter and grower phases (Table 1) was formulated to meet the nutrient requirements of the birds according to the recommendations of NRC (1994). The proximate composition of the diets (Table 2) was determined by the methods of AOAC (2000). On d 35, two birds per replicate were sacrificed by cervical dislocation, and a section of the ileum (the portion of the small intestine extending from the vitelline diverticulum to a point $40 \mathrm{~mm}$ proximal to the ileo-caecal junction) was removed. An approximately $2-\mathrm{cm}$ segment from the two-thirds portion of the ileum from the ileo-caecal junction was further excised, flushed with distilled water and immediately preserved in 10\% buffered formalin solution, and processed to measure villus height and crypt depth. Microbial count was done using the methods described by Barrow \& Feltharn (1993). Media were prepared according to manufacturer's specification. The standard plate count technique was used to determine the microbial load. One millimetre of the digesta was used for serial dilution in sterile $15 \mathrm{~mL}$ test tubes, containing $9 \mathrm{~mL} 0.1 \%$ sterile peptone water and vortexed. Serial dilution of digesta was made to $10^{-3}$ dilution level. One $\mathrm{mL}$ of the dilution was pipetted and inoculated on plate count agar and MacConkey agar, and was incubated at $37^{\circ} \mathrm{C}$ for $18-24 \mathrm{~h}$. Discrete colonies on plates were counted using a colony counter and estimated in log10 CFU/mL.

Data obtained were subjected to analysis of variance (ANOVA) using the statistical analysis software package of SAS (2005). Means were separated, using Tukey's honest significant difference test of this package, and significant level of $P<0.05$ was used.

Table 2 Analysed proximate composition of experimental diets for starter and grower phases

\begin{tabular}{lllllcc}
\hline \multirow{2}{*}{ Growth period } & Item & \multicolumn{5}{c}{ Treatment diet $^{1}$} \\
\cline { 3 - 6 } Starter, d 0 - 21 & NC & PC & NC + OA & NC + PB & NC + OA + PB \\
\hline & Dry matter, g/kg & 910 & 915 & 920 & 905 & 915 \\
& Gross energy, MJ/kg & 18.3 & 18.3 & 18.3 & 18.3 & 18.3 \\
& Crude protein, g/kg & 225 & 223 & 225 & 227 & 224 \\
& Ash, g/kg & 60.0 & 50.0 & 70.0 & 60.0 & 60.0 \\
& Crude fat, g/kg & 34.5 & 35.1 & 34.9 & 35.0 & 34.6 \\
& Ca, g/kg & 9.87 & 10.3 & 10.3 & 10.4 & 10.5 \\
& Total P, g/kg & 7.15 & 7.46 & 7.39 & 7.54 & 7.62 \\
& Crude fibre, g/kg & 33.7 & 33.5 & 33.6 & 33.5 & 33.8 \\
& & & & & & \\
Grower, d 22 - 35 & Dry matter, g/kg & 905 & 895 & 895 & 900 & 895 \\
& Gross energy, MJ/kg & 18.2 & 18.2 & 18.2 & 18.2 & 18.2 \\
& Crude protein, g/kg & 207 & 207 & 207 & 207 & 206 \\
& Ash, g/kg & 60.0 & 60.0 & 60.0 & 60.0 & 70.0 \\
& Ca, g/kg & 9.95 & 9.98 & 9.83 & 9.27 & 9.36 \\
& Total P, g/kg & 7.28 & 7.35 & 7.18 & 7.08 & 7.11 \\
& Crude fat, g/kg & 36.1 & 36.4 & 36.0 & 35.9 & 36.4 \\
& Crude fibre, g/kg & 30.7 & 30.7 & 30.9 & 31.0 & 30.7 \\
& & & & & & \\
\hline
\end{tabular}

\footnotetext{
${ }^{1} \mathrm{NC}$ : negative control; PC: positive control; OA: organic acid; PB: probiotic.
} 


\section{Results and Discussion}

The performances of broilers are shown in Table 3. Diet did not affect feed intake, dry matter intake and feed conversion ratio. Body weight gain of chicks on the OA diet in the starter phase was higher $(P$ $<0.05)$ than that of chicks in the PC and other diets. Gain : feed ratio was improved $(P<0.05)$ in the starter phase only by $\mathrm{OA}$ and $\mathrm{PB}$ supplementation compared with the other diets. Performance showed a significant growth-promoting effect by $\mathrm{OA}$ and $\mathrm{PB}$. The significant effect of $\mathrm{OA}$ on body weight gain is similar to the findings of Dibner \& Buttin (2002) that organic acids have effects that go beyond those of antibiotics, which include reduction in digesta $\mathrm{pH}$, increased pancreatic secretion and trophic consequences on the gastrointestinal mucosa. The dietary additions of organic acids and probiotic had no significant effects on performance traits, indicating a lack of additive effect of both dietary supplements. Generally, there are inconsistencies in reports in the literature on the beneficial effects of probiotics and organic acids on broiler growth performance. Angel et al. (2005) recorded that under favourable rearing conditions, without disease or stress, dietary supplementation with probiotics had no beneficial effects on broiler growth performance. In a study by Timmerman et al. (2006), it was reported that the positive effects of probiotics on highperformance broilers were lower than in low-performing birds. Houshmand et al. (2012), in agreement with the results of Hernandez et al. (2006), did not find positive effects of organic acid (formic acid) on performance. In this study, body weight gain was significantly affected by organic acid in the starter phase.

Table 3 Performance of broilers fed experimental diets

\begin{tabular}{|c|c|c|c|c|c|c|}
\hline \multirow[b]{2}{*}{$\begin{array}{l}\text { Growth } \\
\text { period }\end{array}$} & \multirow[b]{2}{*}{$\begin{array}{l}\text { Treatment } \\
\text { diet }^{2}\end{array}$} & \multicolumn{5}{|c|}{ Parameters $^{1}$} \\
\hline & & $\begin{array}{c}\text { Body } \\
\text { weight } \\
\text { gain, } \\
\text { g/chick }\end{array}$ & $\begin{array}{c}\text { Feed intake, } \\
\text { g/chick }\end{array}$ & $\begin{array}{c}\text { Dry matter } \\
\text { intake, } \\
\text { g/chick }\end{array}$ & FCR & $\begin{array}{c}\text { Gain : Feed, } \\
\text { g/kg/chick }\end{array}$ \\
\hline \multirow{7}{*}{$0-21 d$} & NC & $586^{b}$ & 867 & 819 & 1.51 & $676^{\mathrm{b}}$ \\
\hline & PC & $595^{b}$ & 872 & 773 & 1.45 & $712^{b}$ \\
\hline & $\mathrm{NC}+\mathrm{OA}$ & $681^{a}$ & 935 & 860 & 1.37 & $729^{a}$ \\
\hline & $\mathrm{NC}+\mathrm{PB}$ & $623^{b}$ & 871 & 789 & 1.39 & $725^{a}$ \\
\hline & $\mathrm{NC}+\mathrm{OA}+\mathrm{PB}$ & $557^{\mathrm{b}}$ & 777 & 711 & 1.53 & $643^{b}$ \\
\hline & SEM & 22.2 & 48.2 & 42.2 & 0.015 & 19.0 \\
\hline & $P$-value & 0.008 & 0.1987 & 0.1788 & 0.1231 & 0.0489 \\
\hline \multirow[t]{7}{*}{$22-35 d$} & $\mathrm{NC}$ & 735 & 1416 & 1317 & 1.93 & 518 \\
\hline & PC & 771 & 1450 & 1296 & 1.85 & 532 \\
\hline & $\mathrm{NC}+\mathrm{OA}$ & 794 & 1507 & 1349 & 1.90 & 525 \\
\hline & $\mathrm{NC}+\mathrm{PB}$ & 735 & 1417 & 1275 & 2.01 & 514 \\
\hline & $\mathrm{NC}+\mathrm{OA}+\mathrm{PB}$ & 706 & 1273 & 1139 & 1.95 & 509 \\
\hline & SEM & 37.5 & 72.5 & 59.1 & 0.03 & 21.1 \\
\hline & $P$-value & 0.5141 & 0.1863 & 0.1476 & 0.5744 & 0.9543 \\
\hline \multirow[t]{7}{*}{$0-35 d$} & $\mathrm{NC}$ & $1321^{b}$ & 2283 & 2136 & 1.73 & 579 \\
\hline & $\mathrm{PC}$ & $1366^{b}$ & 2322 & 2069 & 1.67 & 599 \\
\hline & $\mathrm{NC}+\mathrm{OA}$ & $1475^{a}$ & 2442 & 2209 & 1.66 & 604 \\
\hline & $\mathrm{NC}+\mathrm{PB}$ & $1367^{b}$ & 2288 & 2064 & 1.71 & 592 \\
\hline & $\mathrm{NC}+\mathrm{OA}+\mathrm{PB}$ & $1264^{b}$ & 2050 & 1850 & 1.77 & 561 \\
\hline & SEM & 46.2 & 115 & 96.1 & 0.008 & 16.4 \\
\hline & $P$-value & 0.0496 & 0.1562 & 0.1335 & 0.2244 & 0.4132 \\
\hline
\end{tabular}

\footnotetext{
${ }^{1}$ Values are means of six replicate pens of eight birds each. FCR: feed conversion ratio. SEM: standard error of mean.

${ }^{2} \mathrm{NC}$ : negative control; PC: positive control; OA: organic acid; PB: probiotic.

${ }^{\mathrm{a}, \mathrm{b}}$ Means in column in each growth period with different superscripts are significantly different at $P<0.05$.
} 
It can be concluded, in agreement with Yang et al. (2009), that the inconsistencies of reports on the effects of these feed additives on performance could be related to factors such as the environment, management, nutrition, type of additive, dosage and bird characteristics (age, species, stage of production).

The effects of the diets on organ weight and gut morphology are shown on Table 4. Diet had no effects on lung, heart, spleen, liver, kidney and villus width. The villus crypt is regarded as the villus factory, and deeper crypts indicate fast tissue turnover to permit renewal of the villus as needed in response to normal sloughing or inflammation from pathogens or their toxins and high demands for tissue (Yason et al., 1987). There was a significant increase $(P<0.05)$ in the villus height and depth of the intestinal crypt of birds fed OA, PB, and PC compared with NC, but crypt depth decreased in the NC + OA + PB group. Xu et al. (2003) reported that decreased crypts depth may lead to poor nutrient absorption, increased secretion in the gastrointestinal tract and lower performance.

Table 4 Organ weight (g/100 g bodyweight) and gut morphology of birds fed experimental diets

\begin{tabular}{lccccccc}
\hline \multirow{2}{*}{ Item } & \multicolumn{7}{c}{ Treatment diet $^{\mathbf{1 , 2}}$} \\
\cline { 2 - 5 } & NC & PC & NC + OA & NC + PB & NC + OA + PB & SEM & P-value \\
\hline Lung & 0.54 & 0.61 & 0.62 & 0.60 & 0.62 & 0.030 & 0.7705 \\
Heart & 0.50 & 0.48 & 0.49 & 0.50 & 0.52 & 0.028 & 0.8781 \\
Spleen & 0.11 & 0.08 & 0.10 & 0.09 & 0.13 & 0.013 & 0.2423 \\
Kidney & 0.61 & 0.48 & 0.59 & 0.58 & 0.60 & 0.048 & 0.3428 \\
Liver & 2.55 & 2.49 & 2.50 & 2.53 & 2.41 & 0.093 & 0.8491 \\
Bursa of Fabricius & $0.11^{\mathrm{a}}$ & $0.10^{\mathrm{a}}$ & $0.08^{\mathrm{b}}$ & $0.14^{\mathrm{a}}$ & $0.20^{\mathrm{a}}$ & 0.018 & 0.0010 \\
Pancreas & $0.22^{\mathrm{c}}$ & $0.25^{\mathrm{b}}$ & $0.26^{\mathrm{b}}$ & $0.31^{\mathrm{a}}$ & $0.28^{\mathrm{b}}$ & 0.019 & 0.0412 \\
Villus height, mm & $12.0^{\mathrm{b}}$ & $17.6^{\mathrm{a}}$ & $18.0^{\mathrm{a}}$ & $19.3^{\mathrm{a}}$ & $15.8^{\mathrm{a}}$ & 0.950 & 0.0004 \\
Crypt depth, mm & $1.74^{\mathrm{b}}$ & $2.09^{\mathrm{a}}$ & $2.10^{\mathrm{a}}$ & $2.09^{\mathrm{a}}$ & $2.01^{\mathrm{b}}$ & 0.071 & 0.0305 \\
Villus width, mm & 2.21 & 2.59 & 2.25 & 2.27 & 2.29 & 0.160 & 0.4883 \\
Villus height : crypt depth & 6.90 & 8.42 & 8.95 & 9.23 & 7.86 & 0.601 & 0.4059
\end{tabular}

${ }^{1}$ Values are mean of six replicates of one bird each; SEM: standard error of mean.

${ }^{2} \mathrm{NC}$ : negative control; PC: positive control; OA: organic acid; PB: probiotic.

${ }^{a, b, c}$ Means in same row but with different superscripts are significantly different at $P<0.05$.

Similar results were observed by Hernandez et al. (2006) with formic acid, which increased the crypt depth of the small intestine. Garcia et al. (2007) observed improved villus height and significant increase in crypt depth, but villus surface area was not influenced. Abdel-Fattah et al. (2008) reported that the addition of any level and source of organic acid enhanced feed digestion and absorption because of increased small intestine density, which is an indication of the intestinal villi dimension. The weight of the bursa of Fabricius was significantly reduced in the OA diet compared with the other diets. This result is presumably because the bursa of Fabricius plays an important role in developing immunity against Gumboro in chickens. With an attenuated strain of Gumboro virus colonizing the bursa, it atrophied by three to six times between 8 and 10 days post infection. The recovery phase could last up to 35 days, depending on the virulence of the virus strains. The size of the bursa of Fabricius becomes smaller as bodyweight increases, resulting in a lower bursa weight to bodyweight ratio, linked mostly with improved absorption of nutrients by the addition of OA. Similarly to the PC diet, the OA, PB and OA + PB diets significantly increased the weight of the pancreas. The pancreas plays an essential role in digestion and regulation of blood sugar, and contains pancreatic juices that bring about its enlargement for efficient digestion processes of fats, carbohydrates and proteins from the addition of OA and PB. Crypt depth increased significantly $(P<0.05)$ in the OA and PB diets, similar to the PC diet, but was lower in the NC + OA + PB group. This could be because of a synergic effect of OA and PB. The effects of diets on the intestinal microbiota are shown in Table 5.

There were no effects of diet on the coliform count in the duodenum, ileum, colon and caecum, and total bacteria count in the ileum and caecum, but the coliform and total bacteria counts were lower in the OA diet compared with the other diets. These findings are similar to those reported by Ramarao et al. (2004), who found that the addition of gut acidifier in broiler diets at the rate of $300 \mathrm{~g} / 100 \mathrm{~kg}$ feed showed a reduction 
in coliform count. Fumaric and sorbic acid lowered the numbers of coliforms in the ileum and caeca (Pirgozliev et al., 2008). This result agrees with other findings that reported that probiotics benefit the host animal by stimulating synthesis of vitamins of the B-group, improving immunity stimulation, preventing harmful microorganisms, providing digestive enzymes and increasing production of volatile fatty acids (Coates \& Fuller, 1977; Fuller, 1989; Rolfe, 2000). However, acidification of diets with weak organic acids such as formic, fumaric, propionic, lactic and sorbic has been reported to decrease the colonization of pathogens and production of toxic metabolites, improve the digestibility of protein and $\mathrm{Ca}, \mathrm{P}, \mathrm{Mg}$ and $\mathrm{Zn}$, and serve as substrates in intermediary metabolism (Kirchgessner \& Roth, 1988). These findings show that organic acids can safely replace antibacterial compounds in broiler chicken diets with beneficial effects on the intestinal bacterial colonization. There were no significant $(P>0.05)$ differences in the gut microbiota of birds on dietary treatments, although broilers fed the organic acid-supplemented diet had an increased lactobacillus count in the duodenum, ileum and colon. The result is similar to the findings of Thirumeignanam et al. (2006), who reported a decrease in total bacterial load with concomitant increase in lactobacilli load because of dietary acidification. Alp et al. (1999) reported that the inclusion of an antibiotic and an organic acid mixture that contains lactic, fumaric, propionic, citric and formic acid separately or combined, reduced the Enterobacteriaceae count in the ileum of broilers. Thompson \& Hinton (1997) related that an organic acid mixture of formic and propionic acid treatment decreased Salmonella in the crops of hens. Gunal et al. (2006) reported that the addition of probiotics alone or a combination of probiotics with organic acid mixture treatments to diets decreased ileal and caecal gram-negative bacteria counts at 21 days or at 42 days. Engberg et al. (2000) found that Enterococcus faecium (Cylactin) treatments to diets reduced aerobic and coliform bacteria counts.

Table 5 Microflora count $\left(\times 10^{5} \mathrm{CFU}\right)$ in digestive tract of birds on experimental diets

\begin{tabular}{|c|c|c|c|c|c|c|c|c|}
\hline \multirow{2}{*}{ Microflora count ${ }^{3}$} & \multirow{2}{*}{ Gut section } & \multicolumn{5}{|c|}{ Treatment diet ${ }^{1,2}$} & \multirow{2}{*}{ SEM } & \multirow{2}{*}{$P$-value } \\
\hline & & NC & PC & $\mathrm{NC}+\mathrm{OA}$ & $\mathrm{NC}+\mathrm{PB}$ & $\mathrm{NC}+\mathrm{OA}+\mathrm{PB}$ & & \\
\hline \multirow{4}{*}{$\begin{array}{l}\text { Total bacterial } \\
\text { count }\end{array}$} & Duodenum & 7.21 & 2.74 & 5.93 & 2.58 & 5.94 & 2.26 & 0.5345 \\
\hline & Ileum & 34.6 & 6.51 & 3.47 & 11.7 & 20.9 & 9.70 & 0.2120 \\
\hline & Colon & 15.6 & 5.80 & 10.4 & 32.9 & 10.9 & 9.31 & 0.3231 \\
\hline & Caecum & 34.0 & 21.6 & 19.4 & 32.2 & 34.7 & 12.6 & 0.8778 \\
\hline \multirow[t]{4}{*}{ Coliform } & Duodenum & 1.82 & 1.20 & 0.22 & 0.29 & 1.74 & 0.88 & 0.5862 \\
\hline & Ileum & 0.40 & 0.56 & 0.36 & 0.80 & 0.60 & 0.63 & 0.4879 \\
\hline & Colon & 0.50 & 0.41 & 0.12 & 0.33 & 0.31 & 0.46 & 0.4416 \\
\hline & Caecum & 0.17 & 0.13 & 0.13 & 0.15 & 0.14 & 0.06 & 0.3367 \\
\hline \multirow[t]{4}{*}{ Lactic acid bacteria } & Duodenum & 0.87 & 1.29 & 6.46 & 1.30 & 3.33 & 2.57 & 0.3923 \\
\hline & Ileum & 1.28 & 4.73 & 6.95 & 6.94 & 5.70 & 3.36 & 0.7455 \\
\hline & Colon & 8.51 & 12.30 & 14.10 & 8.38 & 6.30 & 8.69 & 0.4317 \\
\hline & Caecum & 16.0 & 16.6 & 19.5 & 43.2 & 35.5 & 13.9 & 0.5398 \\
\hline
\end{tabular}

${ }^{1} \mathrm{NC}$ : negative control; PC: positive control; OA: organic acid; PB: probiotic.

${ }^{2}$ Values are means of six replicate pens of two birds each. SEM: standard error of mean.

\section{Conclusion}

The inclusion of organic acid and probiotic alone in diets with no antibiotics improved body weight gain in the starter phase and overall period. But this advantage was not obtained when the additives were added in combination to the NC diet. Organic acid, probiotics and a combination of the two improved gut morphology, increased the weight of the pancreas and reduced pathogenic bacteria in the gut. 


\section{References}

Abdel-Fattah, S.A., El-Sanhoury, M.H., El-Mednay, N.H. \& Abdel-Azeem, F., 2008. Thyroid activity, some blood constituents, organ morphology and performance of broiler chicks fed supplemental organic acids. Int. J. Poult. Sci. 7, 215-222.

Alp, M., Kocabagli, M., Kahraman, R. \& Bostan, K., 1999. Effects of dietary supplementation with organic acids and zinc bacitracin on ileal microflora, $\mathrm{pH}$ and performance in broilers. Turk. J. Vet. Anim. Sci. 23, 451-455.

Angel, R., Dalloul, R.A. \& Doerr J., 2005. Performance of broiler chickens fed diets supplemented with a Direct-Fed Microbial. Poult. Sci. 84, 1222-1231.

AOAC, 2000. Official Method of Analytical Chemists. 16th ed. Arlington, VA, USA.

Ashayerizadeh, A., Dabiri, N., Mirzadeh, K.H. \& Ghorbani, M.R., 2011. Effect of dietary supplementation of probiotic and prebiotic on growth indices and serum biochemical parameters of broiler chickens. $\mathrm{J}$. Cell Anim. Biol. 5, 152-156.

Barrow, G.H. \& Feltham, R.K.A., 1993. Cowan and Steel's Manual for Identification of Medical Bacteria. 3rd ed. Cambridge University Press, Cambridge. pp. 331.

Coates, M.E. \& Fuller, R., 1977. The genetobiotic animal in the study of gut microbiology. In: Microbial Ecology of the Gut. Eds: Clarke, R.T.J. \& Bauchop, T., Academic Press, London. pp. 311-346.

Dibner, J.J. \& Buttin, P., 2002. Use of organic acids as a model to study the impact of gut microflora on nutrition and metabolism. J. Appl. Poult. Res. 11, 453-463.

Engberg, R.M., Hedemann, M.S., Leser, T.D. \& Jensen, B.B., 2000. Effect of zinc bacitracin and salinomycin on intestinal microflora and performance of broilers. Poult. Sci. 79, 1311-1319.

Fuller, R., 1989. Probiotics in man and animals. A review. J. Appl. Bact. 66, 365-378.

Gaggia, F., Mattarelli, P. \& Biavati, B., 2010. Probiotics and prebiotics in animal feeding for safe food production. Int. J. Food Microb. 141, S15-S28.

Garcia V., Catala-Gregori, P., Hernandez, F., Megias, M.D. \& Madrid, J., 2007. Effect of formic acid and plant extracts on growth, nutrient digestibility, Intestinal mucosa morphology, and meat yield of broilers. J. Appl. Poult. Res. 16, 555-562.

Gunal, M., Yayli, G., Kaya, O., Karahan, N. \& Sulak, O., 2006. The effects of antibiotic growth promoter, probiotic or organic acid supplementation on performance, intestinal microflora and tissue of broilers. Int. J. Poult. Sci. 5, 149-155.

Hernandez, F., Garcia, V., Madrid, J., Orengo, J., Catala, P. \& Megias, M.D., 2006. Effect of formic acid on performance, digestibility, intestinal histomorphology and plasma metabolite levels of broiler chickens. Br. Poult. Sci. 47, 50-67.

Houshmand, M., Azhar, K., Zulkifli, I., Bejo, M.H. \& Kamyab, A., 2012. Effects of non-antibiotic feed additives on performance, immunity and intestinal morphology of broilers fed different levels of protein. S. Afr. J. Anim. Sci. 42, 22-32.

Kirchgessner, M. \& Roth, M.X., 1988. Ergotrope Efekte durch organische Suaren in der Ferkelaufzucht und Schweinemast. Ubersichten zur Tierernahrung 16, 93-108. (in German)

Miles, R.D., Janky, D.M. \& Harms, R.H., 1984. Virginiamycin and broiler performance. Poult. Sci. 63, 1218-1221.

NRC, 1994. Nutrient Requirements of Poultry. (9th ed.). National Academy Press, Washington, D.C., USA.

Pirgozliev, V., Murphy, T.C., Owens, B., George, J. \& McCannin, M.E.E., 2008. Fumaric and sorbic acid as additives in broiler feed. Res. Vet. Sci. 84, 387-394.

Ramarao, S.V., Reddy, M.R., Rajuand, M.V.L.N. \& Panda, A.K., 2004. Growth, nutrient utilization and immune-competence in broiler chicken fed probiotic, gut acidifier and antibacterial compounds. Indian J. Poult. Sci. 39, 125-130.

Rolfe, R.E., 2000. The role of probiotic cultures in the control of gastrointestinal health. J. Nutr. 130, 396-402.

SAS, 2005. Statistical Analysis Systems users guide (9th ed.). SAS Institute Inc., Cary, N.C., USA.

Thirumeignanam, D., Swain, R.K., Mohanty, S.P. \& Pati, P.K., 2006. Effects of dietary supplementation of organic acids on performance of broiler chicken. J. Anim. Nutr. 23, 34-40

Thompson, J.L. \& Hinton, M., 1997. Antibacterial activity of formic and propionic acids in the diets of hens on salmonellas in the crop. Br. Poult. Sci. 38, 59-65.

Timmerman, H.M., Veldman, A., Van den Elsen, E., Rombouts, F.M. \& Beynen, A.C., 2006. Mortality and growth performance of broilers given drinking water supplemented with chicken-specific probiotics. Poult. Sci. 85, 1383-1388.

Thompson, J.L. \& Hinton, M., 1997. Antibacterial activity of formic and propionic acids in the diets of hens on Salmonellas in the crop. Br. Poult. Sci. 38, 59-65.

Truscott, R.B. \& Al-Sheikhly, F., 1977. The production and treatment of necrotic enteritis in broilers. Am. J. Vet. Res. 38, 857-861. 
Waldroup, P.W., Spencer, G.K., Waibeal, P.E., Quarles, C.L. \& Grant, R.J., 1985. The use of bambermycins (flavomycin) and halofuginone (stenorol) in diets for growing turkey. Poult. Sci. 64, 1296-1301.

Xu, Z.R., Hu, C.H., Xia, M.S., Zhan, X.A. \& Wang, M.Q., 2003. Effects of dietary fructooligosaccharide on digestive enzyme activities, intestinal microflora and morphology of male broilers. Poult. Sci. 82, 1030-1036.

Yalcinkaya, I., Gungor, T., Basalan, M. \& Erdem, E., 2008. Mannan oligosaccharides (MOS) from Saccharomyces cerevisiae in broilers: Effects on performance and blood biochemistry. Turk. J. Vet. Anim. Sci. 32, 1-6.

Yang, Y., Iji, P.A., Kocher, A., Thomson, E., Mikkelsen, L.L. \& Choct, M., 2008. Effects of mannanoligosaccharide in broiler chicken diets on growth performance, net energy utilization, nutrient digestibility, and intestinal microflora. Br. Poult. Sci. 49, 186-194.

Yang, Y., lji, P.A. \& Choct, M., 2009. Dietary modulation of gut microflora in broiler chickens: A review of the role of six kinds of alternatives to in-feed antibiotics. World's Poult. Sci. J. 65, 97-114.

Yason, C.V., Summers, B.A. \& Schat, K.A., 1987. Pathogenesis of rotavirus infection in various age groups of chickens and turkeys: Pathology. Am. J. Vet. Res. 6, 927-938.

Yusrizal, X.N. \& Chen, T.C., 2003. Effect of adding chicory fructans in feed on fecal and intestinal microflora and excreta volatile ammonia. Int. J. Poult. Sci. 2, 188-194. 